University of Nebraska - Lincoln

DigitalCommons@University of Nebraska - Lincoln

Roman L. Hruska U.S. Meat Animal Research

U.S. Department of Agriculture: Agricultural Center

Research Service, Lincoln, Nebraska

2004

\title{
Comparison of Longhorn- and Red Poll-Sired Calves from Crossbred Dams Calving at Two or Three Years of Age
}

\author{
X H. Liu \\ University of Nebraska, Lincoln \\ A Perez Marquez \\ University of Nebraska, Lincoln \\ L. V. Cundiff \\ U.S. Meat Animal Research Center, Larry.Cundiff@ars.usda.gov \\ L. D. Van Vleck \\ USDA, ARS, Roman L. Hruska U.S. Meat Animal Research Center, Lincoln, NE
}

Follow this and additional works at: https://digitalcommons.unl.edu/hruskareports

Part of the Animal Sciences Commons

Liu, X H.; Perez Marquez, A; Cundiff, L. V.; and Van Vleck, L. D., "Comparison of Longhorn- and Red PollSired Calves from Crossbred Dams Calving at Two or Three Years of Age" (2004). Roman L. Hruska U.S. Meat Animal Research Center. 163.

https://digitalcommons.unl.edu/hruskareports/163

This Article is brought to you for free and open access by the U.S. Department of Agriculture: Agricultural Research Service, Lincoln, Nebraska at DigitalCommons@University of Nebraska - Lincoln. It has been accepted for inclusion in Roman L. Hruska U.S. Meat Animal Research Center by an authorized administrator of DigitalCommons@University of Nebraska - Lincoln. 


\title{
Crit \\ Comparison of Longhorn- and Red Poll-Sired Calves from Crossbred Dams Calving at Two or Three Years of Age
}

\author{
X. H. LIU*,2 ${ }^{*}$ A. PÊREZ MARQUEZ* ${ }^{*}$ L. V. CUNDIFF ${ }^{\dagger, 3}$, PAS, and L. D. VAN VLECK \\ *Department of Animal Science, University of Nebraska, Lincoln 68583-0908; †USDA, ARS, Roman L. \\ Hruska U.S. Meat Animal Research Center, Clay Center, NE 68933; and ${ }^{\ddagger}$ USDA, ARS, Roman L. \\ Hruska U.S. Meat Animal Research Center, Lincoln, NE 68583-0908
}

\section{Abstract}

Calving difficulty, survival from birth to weaning, birth weight, and weaning weight of 167 calves and carcass traits of 88 cattle (63 for adjusted fat thickness) were compared for progeny of Red Poll and Longhorn bulls mated to crossbred cows that calved at 2 or $3 \mathrm{yr}$ of age. Results indicated that Longhornsired calves required $28 \%$ less assistance at calving than Red Poll-sired calves when dams calved at 2 yr of age $(P<0.05)$, but there was no difference between Red Poll- and Longhorn-sired calves for calving difficulty with 3- yr-old cows. Red Poll-sired calves had significantly greater birth and weaning $B W$ than did Longhorn-sired calves for 2-yrold dams. Significant differences attribut-

\footnotetext{
${ }^{1}$ Published as Journal Series no.13795, Nebraska Agric. Res. Div., Univ. of Nebraska, Lincoln 68583-0908.

${ }^{2}$ Current address: College of Animal Science and Technology, Yunnan Agricultural University, Kunming City, Yunnan Province, People's Republic of China.

${ }^{3}$ To whom correspondence should be addressed: cundiff@email.marc.usda.gov
}

able to sire breed were found only for bone percentage of progeny of 3-yr-old dams, but not for carcass weight, fat thickness, longissimus area, USDA quality grades, and percentages retail product, fat trim, or bone. There was a significant interaction between sire breed and age of dam only for calving difficulty. Within sire breed, calving difficulty of 2$y r$-old dams was greater than that for 3yr-old dams, and calves from 2-yr-old dams also were significantly lighter at weaning than were calves from 3-yr-old dams $(P<0$.01).

(Key Words: Calving Difficulty, Carcass, Crossbreeding, Growth.)

\section{Introduction}

Longhorn and Red Poll bulls have the reputation of siring calves that are born with little dystocia. Thus, these sire breeds are often recommended for mating to heifers to reduce incidence of calving difficulty, but with the recognition that benefits of less calving difficulty may be partially offset by unfavorable effects on growth to weaning and slaughter ages. Previous results from the Germplasm Evaluation (GPE) project at the U.S. Meat Animal Research Center are consistent with this recommendation, but birth weights and calving difficulty have been reported previously only for progeny of Longhorn and Red Poll sires produced by cows calving at $4 \mathrm{yr}$ of age or older in this program, and this subset normally experiences less calving difficulty (Cundiff et al., 1993). Gregory et al. (1978) reported that progeny of Red Poll, Hereford, and Angus sires had significantly lighter birth weights, less calving difficulty, and greater survival to weaning than progeny of Maine Anjou, Chianina, and Gelbvieh sires. Cundiff et al. (1998) reported that calving difficulty and birth weights were significantly less for progeny of Longhorn sires than for Hereford-Angus reciprocal crosses, but survival was not significantly different. Thrift et al. (1986) reported that progeny of Longhorn sires were $5.9 \mathrm{~kg}$ lighter at birth and $26 \mathrm{~kg}$ lighter at weaning than progeny of Red Poll bulls and crossbred dams with various proportions of Angus, Brahman, Charolais, and Hereford breeding calving at 2 and $3 \mathrm{yr}$ of age. Calving difficulty was not reported, but the calves were produced in a subtropical region (Louisiana), where birth weights are known to be significantly lighter (8 
$\mathrm{kg}$ ) and incidence of calving difficulty is less than that found in a temperate region (Nebraska) of the U.S. (Olson et al., 1991). Koch et al. (1979) compared carcass traits of steers for several sire breeds including Red Poll but not Longhorn. The primary objective of the present study was to compare Longhorn- and Red Poll-sired progeny from crossbred dams calving at 2 or $3 \mathrm{yr}$ of age for calving traits, weights at weaning and slaughter, and carcass traits.

\section{Materials and Methods}

Data for this study were from Cycle III of the GPE project at the U.S. Meat Animal Research Center and specifically were from calves born in 1985, 1986, 1987, 1988, and 1989 resulting from multi-sire clean-up matings to Red Poll and Longhorn bulls. A total of 8 Red Poll and 11 Longhorn bulls were used. The Red Poll bulls were sampled from a broadbased purebred herd maintained as part of the Germplasm Utilization Project at the U.S. U.S. Meat Animal Research Center (Gregory et al., 1991). The Longhorn bulls were sampled from the herd of purebred Longhorn cattle maintained at the Fort Niobrara National Wildlife Refuge (Valentine, NE). Two or more bulls of each sire breed, Red Poll or Longhorn, were run together in separate pastures during the 21-d natural service clean-up mating period each year. The cows were $F_{2}$ and reciprocal backcrosses born in 1983 through 1986 out of F1 cross dams that had been produced in 1975 and 1976 from original matings of Hereford, Angus, Pinzgauer, Brahman, and Sahiwal bulls to Hereford and Angus cows. The $\mathrm{F}_{2}$ and reciprocal backcross cows calved as 2-yr olds in 1985 through 1988 and as 3-yr olds in 1986 through 1989. The number of calves produced by each sire breed, breed group of dam, and age of dam are shown in Table 1.

Calves were born from early April to late May. Male calves were castrated within $24 \mathrm{~h}$ of birth. Calves

TABLE 1. Number of calves born and number slaughtered by sire breed $^{a}$, breed group of dam, and age of dam.

\begin{tabular}{|c|c|c|c|c|c|c|}
\hline \multirow[b]{2}{*}{ Item } & \multicolumn{2}{|c|}{ 2-yr-old dams } & \multicolumn{2}{|c|}{ 3-yr-old dams } & \multicolumn{2}{|c|}{ Total } \\
\hline & LT & $C T^{b}$ & LT & CT & LT & CT \\
\hline \multicolumn{7}{|l|}{ Sire of calf } \\
\hline Red Poll & 58 & 40 (15) & 28 & 9 & 86 & 49 \\
\hline Longhorn & 37 & $21(21)$ & 44 & 18 & 81 & 39 \\
\hline \multicolumn{7}{|l|}{ Dam of calf } \\
\hline $1 / 4 \mathrm{H} 3 / 4 \mathrm{~A}$ & 7 & $4(2)$ & 6 & 2 & 13 & 6 \\
\hline $1 / 2 \mathrm{H} 1 / 2 \mathrm{~A}$ & 10 & $9(4)$ & 6 & 2 & 16 & 11 \\
\hline $3 / 4 \mathrm{H} 1 / 4 \mathrm{~A}$ & 13 & $8(4)$ & 6 & 4 & 19 & 12 \\
\hline $1 / 4 \mathrm{P} 3 / 4(\mathrm{~A}$ or $\mathrm{H})$ & 2 & $1(1)$ & 7 & 2 & 9 & 3 \\
\hline $1 / 2$ P $1 / 2(\mathrm{~A}$ or $\mathrm{H})$ & 3 & $2(0)$ & 1 & 1 & 4 & 3 \\
\hline $3 / 4$ P $1 / 4(\mathrm{~A}$ or $\mathrm{H})$ & 5 & $3(3)$ & 1 & 0 & 6 & 3 \\
\hline $1 / 4 B 3 / 4(A$ or $H)$ & 7 & $4(3)$ & 7 & 2 & 14 & 6 \\
\hline $1 / 2 B 1 / 2(A$ or $H)$ & 15 & $10(6)$ & 12 & 5 & 27 & 15 \\
\hline $3 / 4$ B $1 / 4(A$ or $H)$ & 2 & $2(2)$ & 7 & 2 & 9 & 4 \\
\hline $1 / 4 \mathrm{~S} 3 / 4(\mathrm{~A}$ or $\mathrm{H})$ & 8 & $6(2)$ & 4 & 2 & 12 & 8 \\
\hline $1 / 2 S_{1 / 2}(\mathrm{~A}$ or $\mathrm{H})$ & 12 & $8(2)$ & 4 & 0 & 16 & 8 \\
\hline $3 / 4$ S $1 / 4(\mathrm{~A}$ or $\mathrm{H})$ & 7 & $3(2)$ & 6 & 4 & 13 & 7 \\
\hline $1 / 4 \mathrm{~B}^{1 / 4} \mathrm{~S}^{1 / 4} \mathrm{H}^{1 / 4} \mathrm{~A}$ & 4 & $3(3)$ & 5 & 1 & 9 & 4 \\
\hline
\end{tabular}

${ }^{\mathrm{a}} \mathrm{H}=$ Hereford, $\mathrm{A}=$ Angus, $\mathrm{P}=$ Pinzgauer, $\mathrm{B}=$ Brahman, and $\mathrm{S}=$ Sahiwal.

${ }^{b} \mathrm{LT}=$ number of calves born; $\mathrm{CT}=$ number of animals for carcass traits. Number of observations for adjusted fat thickness are shown in parentheses. Adjusted fat thickness was not recorded for steers and heifers produced by 2-yr-old dams in the first year of the experiment (i.e., 1985).

were weaned in September at an average age of 127 d. Following weaning, steers and heifers produced in 1985, 1987, and 1988 were placed in separate pens by sex. They were allowed to adjust to the dry lot for a 6- to 8wk period during which time they were fed a mixture of grass and alfalfa hay free choice and introduced to a mixed diet with approximately $2.63 \mathrm{mcal} \mathrm{ME} / \mathrm{kg} \mathrm{DM}$ and $13.2 \% \mathrm{CP}$ consisting of $43 \%$ corn silage, $31 \%$ corn, $19 \%$ alfalfa hay, and $8 \%$ supplement. In 1985, steers and heifers were fed daily a mixed diet containing about $2.72 \mathrm{Mcal}$ ME/kg DM and $12.88 \% \mathrm{CP}$ consisting of $56 \%$ corn silage, 33\% corn, and 11\% supplement for a 45 -d growing period. Then over $2 \mathrm{mo}$, they were gradually shifted to a finishing diet containing $3.12 \mathrm{Mcal} \mathrm{ME} / \mathrm{kg} \mathrm{DM}$ and 10.4\% CP consisting of $83 \%$ corn, $13 \%$ corn silage, and 4\% supplement. In 1987 and 1988, the steers and heifers were fed a growing diet daily for an ex- tended period of $170 \mathrm{~d}$ containing about $2.24 \mathrm{Mcal} \mathrm{ME} / \mathrm{kg} \mathrm{DM}$ and $12.34 \% \mathrm{CP}$ consisting of $54 \%$ corn silage, $42 \%$ alfalfa haylage, and $4.0 \%$ supplement. Then, over an 8-wk period, they were gradually shifted to daily feeding of a higher concentrate finishing diet containing about 3.04 Mcal ME/kg DM and 10.9\% CP consisting of $70 \%$ corn, $25 \%$ corn silage, and 5\% supplement. Steers and heifers were slaughtered serially at two or three slaughter dates spanning 33 to $52 \mathrm{~d}$ in each year. Steers were slaughtered at an average age of $454 \mathrm{~d}$, and heifers were slaughtered at an average age of $443 \mathrm{~d}$ of age in a commercial abattoir. After a 24-h chill, components of USDA yield grade (adjusted fat thickness; longissimus area; estimated kidney, pelvic, and heart fat percentage; and carcass weight) and USDA quality grade (marbling, maturity) were obtained.

Carcass data were from calves born in 1985, 1987, and 1988. Retail prod- 
TABLE 2. Conversion chart for marbling scores.

\begin{tabular}{lc} 
Item & Numerical \\
\hline Practically devoid & 200 \\
Traces & 300 \\
Slight & 400 \\
Small & 500 \\
Modest & 600 \\
Moderate & 700 \\
Slight abundant & 800 \\
Moderately abundant & 900 \\
& \\
${ }^{a}$ A small marbling score (e.g., 20) was converted to a numerical score of $500+$ \\
$20=520$.
\end{tabular}

uct, fat trim, and bone yields were estimated using the following equations (Shackelford et al., 1995):

Percentage of totally trimmed retail product yield $=74.9$ 5.8402 (adjusted fat thickness, cm) -0.0205 (marbling score) + 0.1018 (longissimus area, $\mathrm{cm}^{2}$ ) 1.0384 (estimated percentage of kidney, pelvic, and heart fat);

Percentage of fat trim yield (totally trimmed) $=5.1+7.5795$ (adjusted fat thickness, $\mathrm{cm})+$ 0.0230 (marbling score) + 1.3632 (estimated percentage of kidney, pelvic, and heart fat) 0.0825(longissimus area, $\mathrm{cm}^{2}$ ); and

Percentage of bone yield $=17.5$ -1.7581 (adjusted fat thickness, cm) -0.3855 (estimated kidney, pelvic, and heart fat percentage).

Weaning weight was adjusted for age of calf (205 d) according to Beef Improvement Federation (BIF) Guidelines (1996). Calf survival was on a binomial scale $(0=$ died before and $1=$ alive at weaning time). Marbling score was on a modified categorical basis as described in BIF Guidelines (1996) and as shown in Table 2. USDA Choice and Standard quality grade were analyzed as binomial traits (Table 3).
Calving difficulty was measured on a categorical scale $(1=$ no difficulty, 2 = little difficulty by hand, $3=$ little difficulty with calf jack, $4=$ slight difficulty with calf jack, $5=$ moderate difficulty with calf jack, $6=$ major difficulty with calf jack, 7 = caesarean birth, and $8=$ abnormal presentation) according to BIF Guidelines (1996). Calving difficulty was analyzed as a binomial trait as described in Table 3. Unadjusted means and standard deviations for preweaning, postweaning, and carcass traits are shown in Table 4.

A fixed effects model was used to analyze the data. For traits measured on the live animal, fixed effects included year of birth, sex at birth or weaning (steers, heifers), calf sire breed, and age of dam. Covariates were calendar birth day and fractions of inheritance from Hereford, Angus, Pinzgauer, Brahman, and Sahiwal dams and also fractions of heterozy- gosity in the dams expected from Bos taurus $\times$ Bos taurus, Bos taurus $\times$ Bos indicus, and Bos indicus $\times$ Bos indicus crosses. Fixed effects and covariates for carcass traits were the same as for live traits, except only sex at weaning was used. Age (d) at weaning and slaughter were additional covariates. No random factors were included, as individual sires were unknown and each dam had only one calf. Analyses were conducted with the MTDFREML programs modified for a fixed effects model (Boldman et al., 1995). Tests of sire breed using the residual error term rather than the more appropriate term of sire within breed (unfeasible because individual sires could not be identified with the use of multiple sires per pasture) were biased. Given that many of the traits studied have a moderate to high heritability, the mean square for sire within breed, if estimable, would be larger than the residual mean square. This concern prompted the use of previous estimates of heritability from reports involving the same traits on animals produced in the GPE Program at the U.S. Meat Animal Research Center (Koch et al., 1982; Wheeler et al., 2001) to partition the residual mean square (expected value $\sim \sigma_{\mathrm{w}}^{2}+\mathrm{k}_{1} \sigma_{\mathrm{s}}^{2}$, where $\mathrm{k}_{1} \sim 0.523$ for preweaning traits and 0.632 for postweaning traits) into residual $\left(\sigma_{\mathrm{w}}^{2}\right)$ and sire $\left(\sigma_{\mathrm{s}}^{2}\right)$ components of variance. The expected mean squares for sire within breed of sire (expected value $\sim \sigma_{\mathrm{w}}^{2}+$ $\mathrm{k}_{2} \sigma_{\mathrm{w}}^{2}$, where $\mathrm{k}_{2} \sim 8.78$ for preweaning traits and 6.76 for postweaning traits) with $9 \mathrm{df}$ for preweaning traits and 7

TABLE 3. Conversion of traits to binomial scale.

\begin{tabular}{lcc} 
Item & Categorical scores & Binomial scale \\
\hline Calving difficulty & 1 and 2 & 0 \\
& 3 to 7 & 1 \\
\multirow{3}{*}{ USDA Choice } & 8 & Not used \\
& Marbling score $<500$ & 0 \\
USDA Standard & Marbling score $\geq 500$ & 1 \\
& Marbling score $>399$ & 0 \\
& Marbling score $\leq 399$ & 1
\end{tabular}


TABLE 4. Unadjusted means and standard deviations (SD).

\begin{tabular}{l} 
Item \\
\hline Calving difficulty, \% \\
Survival birth to weaning, \% \\
Birth BW, kg \\
Weaning BW, kg \\
Live slaughter BW, kg \\
Hot carcass wt., kg \\
Marbling, score \\
Fat thickness, cm \\
Adjusted fat thickness, cm \\
Longissimus area, cm² \\
Kidney, pelvic, and heart fat, \% \\
USDA Choice grade, \% \\
USDA Standard grade, \% \\
Retail product, \% \\
Fat trim, \% \\
Bone, \%
\end{tabular}

\begin{tabular}{cc} 
Mean & SD \\
\hline 10 & 3 \\
98 & 15 \\
31.68 & 5.42 \\
180.66 & 31.46 \\
429.87 & 56.93 \\
259.94 & 38.05 \\
494.21 & 96.69 \\
0.99 & 0.53 \\
0.72 & 0.36 \\
67.35 & 7.55 \\
3.01 & 0.71 \\
43 & 50 \\
16 & 37 \\
64.70 & 3.56 \\
20.10 & 4.58 \\
15.19 & 0.68
\end{tabular}

df for postweaning traits were then used to compute standard errors and approximate $t$ tests for sire breed of calves, sire breed of calves with 2-yrold dams, sire breed of calves with 3yr-old dams, and sire breed $\times$ age of dam interaction (each with $1 \mathrm{df}$ ).

\section{Results and Discussion}

Estimates of linear contrasts and standard errors between sire breeds, ages of dams, and the interaction of sire breed and age of dam are shown in Table 5 for preweaning traits and in Table 6 for postweaning traits measured before slaughter and for carcass traits.

Comparison of Ages of Dam. Calving difficulty for 2-yr-old dams was significantly greater than that for 3yr-old dams. The calves of 2-yr-old dams also were significantly lighter than calves of 3-yr-old dams for weaning weight. No significant differences caused by age of dam were found for other traits.

Comparison of Sire Breeds Across Both Ages of Dam. Results in Table 5 indicate that Red Poll-sired calves had greater calving difficulty $(P<0.05)$ than did Longhorn-sired calves $(P<0.05)$ and tended to have greater $(P<0.10)$ birth and weaning BW. These results were similar to those from previous research for calving difficulty, birth BW, and weaning BW in the GPE Program at the U.S. Meat Animal Research Center (Cundiff et al., 1993) and consistent in direction but only about one-half as great in magnitude as those reported for weights at birth and weaning in Louisiana (Thrift et al., 1986).

Red Poll- and Longhorn-sired calves did not differ significantly in carcass traits (Table 6); however, Red Pollsired cattle tended to have a lower percentage of bone $(P<0.10)$. No significant differences caused by sire breed were found for calf survival; final weight; carcass weight; marbling score; fat thickness; longissimus area; kidney, pelvic, and heart fat percentage; retail product percentage; fat trim percentage; the percentage of carcasses grading USDA Choice or greater; or the percentage of carcasses grading USDA Standard.

Comparison of Calves of Red Poll and Longhorn Sires by Age of Dam. Because age of dam may have an influence on effect of sire breed, the interaction between sire breed and age of dam was also tested for each trait. Results in Table 5 indicate that calving difficulty of Red Poll-sired calves was greater $(P<0.05)$ than that of Longhorn-sired calves when dams

TABLE 5. Estimates of linear contrasts $(\overline{\mathrm{d}})$ and standard errors $(\mathrm{SE})$ for traits measured before slaughter between Red Poll and Longhorn (RP - LH) sire breeds, between ages of dam, and interaction of sire breed and age of dam.

\begin{tabular}{|c|c|c|c|c|c|c|c|c|c|c|}
\hline \multirow[b]{2}{*}{ Item } & \multicolumn{2}{|c|}{$\begin{array}{c}\text { RP - LH } \\
\text { all ages of dams }\end{array}$} & \multicolumn{2}{|c|}{$\begin{array}{c}\text { RP - LH } \\
\text { with 2-yr dams }\end{array}$} & \multicolumn{2}{|c|}{$\begin{array}{c}\text { RP - LH } \\
\text { with 3-yr dams }\end{array}$} & \multicolumn{2}{|c|}{$\begin{array}{c}\text { Sire breed } \\
\times \text { age of dam }\end{array}$} & \multicolumn{2}{|c|}{$\begin{array}{c}\text { 2-yr-old - } \\
\text { 3-yr-old dams }\end{array}$} \\
\hline & $\bar{d}$ & SE & $\bar{d}$ & SE & $\overline{\mathbf{d}}$ & SE & $\overline{\mathbf{d}}$ & SE & $\bar{d}$ & SE \\
\hline Calving difficulty, \% & $14^{*}$ & 6 & $28 *$ & 8 & 0 & 7 & $29 *$ & 11 & $16^{*}$ & 5 \\
\hline Survival to weaning, $\%$ & 0 & 3 & 3 & 4 & -3 & 4 & 6 & 7 & 4 & 3 \\
\hline Birth BW, kg & $2.27^{\dagger}$ & 115 & $3.43^{*}$ & 1.69 & 1.10 & 1.56 & 2.33 & 2.77 & -0.75 & 0.92 \\
\hline Weaning BW, kg & $12.06^{\dagger}$ & 4.95 & $20.82^{*}$ & 9.02 & 3.29 & 8.35 & 17.53 & 12.33 & $-20.07^{*}$ & 5.34 \\
\hline
\end{tabular}


TABLE 6. Estimates of contrasts ( $\bar{d})$ and standard errors (SE) for carcass traits between Red Poll and Longhorn (RP - LH) breeds of sire, between ages of dam, and interaction of sire breed and age of dam (age end point, $448 \mathrm{~d})$.

\begin{tabular}{|c|c|c|c|c|c|c|c|c|c|c|}
\hline \multirow[b]{2}{*}{ Item } & \multicolumn{2}{|c|}{$\begin{array}{c}\text { RP - LH } \\
\text { all ages of dams }\end{array}$} & \multicolumn{2}{|c|}{$\begin{array}{c}\text { RP - LH } \\
\text { with 2-yr dams }\end{array}$} & \multicolumn{2}{|c|}{$\begin{array}{c}\text { RP - LH } \\
\text { with 3-yr dams }\end{array}$} & \multicolumn{2}{|c|}{$\begin{array}{c}\text { Sire breed } \\
\times \text { age of dam } \\
\end{array}$} & \multicolumn{2}{|c|}{$\begin{array}{c}\text { 2-yr-old - } \\
\text { 3-yr-old dams }\end{array}$} \\
\hline & $\bar{d}$ & SE & $\bar{d}$ & SE & $\overline{\mathbf{d}}$ & SE & $\bar{d}$ & SE & $\overline{\mathbf{d}}$ & SE \\
\hline Final BW, kg & 29.83 & 18.07 & $55.62^{\dagger}$ & 25.00 & 4.04 & 27.54 & 51.58 & 38.15 & -19.09 & 13.96 \\
\hline Hot carcass weight, kg & 18.96 & 11.22 & 27.11 & 15.19 & 10.82 & 17.22 & 16.29 & 23.44 & -13.06 & 8.71 \\
\hline Marbling score & 23.44 & 33.17 & 7.91 & 44.85 & 38.96 & 50.82 & -31.04 & 69.18 & 34.94 & 23.48 \\
\hline Fat thickness, $\mathrm{cm}$ & 0.28 & 0.17 & 0.27 & 0.23 & 0.29 & 0.26 & -0.03 & 0.35 & -0.20 & 0.12 \\
\hline Adjusted fat thickness, $\mathrm{cm}$ & $0.26^{\dagger}$ & 0.11 & 0.22 & 0.16 & 0.30 & 0.17 & 0.07 & 0.13 & -0.10 & 0.08 \\
\hline Longissimus area, $\mathrm{cm}^{2}$ & 0.78 & 0.88 & -0.13 & 3.00 & 1.68 & 3.42 & -1.81 & 4.68 & 1.22 & 1.71 \\
\hline Kidney, pelvic, and heart fat, \% & -0.24 & 0.22 & -0.49 & 0.29 & 0.01 & 0.33 & -0.50 & 0.45 & -0.16 & 0.17 \\
\hline USDA Choice, \% & 9 & 19 & 4 & 25 & 14 & 27 & -11 & 39 & -1 & 14 \\
\hline USDA Standard, \% & -6 & 12 & 1 & 17 & -14 & 19 & 16 & 26 & -10 & 10 \\
\hline Retail product, \% & -1.59 & 1.13 & -0.77 & 1.56 & -2.41 & 1.73 & 0.55 & 1.41 & 0.26 & 0.85 \\
\hline Fat trim, $\%$ & 1.92 & 1.40 & 1.28 & 1.93 & 2.56 & 2.13 & -0.16 & 1.75 & -0.48 & 1.07 \\
\hline Bone, \% & $-0.40^{\dagger}$ & 0.20 & -0.28 & 0.27 & -0.53 & 0.30 & -0.17 & 0.24 & 0.30 & 0.16 \\
\hline
\end{tabular}

were 2 yr old. No difference caused by sire breed for calving difficulty was found for 3-yr-old dams. The calves of 2-yr-old dams by Red Poll sires were significantly heavier (Table 5 ; $P<0.05)$ at birth and weaning than were calves of Longhorn sires, and final weight of cattle slaughtered tended to be heavier (Table 6; $P<0.10)$. However, for calves from $3-$ yr-old dams, differences caused by sire breed were not significant for birth, weaning, and slaughter weights. Calves by Red Poll and Longhorn sires mated to dams to calve as 2 -yr olds or as 3-yr olds were not significantly different for survival at weaning or any of the carcass traits studied. Only for calving difficulty was there a significant interaction between sire breed and age of dam.

Results from this experiment are consistent with previous reports from the GPE Program at the U.S. Meat Animal Research Center in which progeny of Red Poll sires were compared with progeny of six other sire breeds in Cycle II (Gregory et al., 1991) and in which progeny of Longhorn sires were compared with progeny of 10 other sire breeds in Cycle IV of the program (Wheeler et al., 1997; Cundiff et al., 1998) when dams were calving at $4 \mathrm{yr}$ of age or older. Hereford-Angus reciprocal crosses produced from matings to reference sires (10 Hereford, and 14 Angus bulls born in the late 1960s) provided ties for analyses pooled over the first four cycles of the GPE Program (Cundiff et al., 1993). Results from this report indicated that Longhorn and Red Poll were comparable in calving ease in cows calving at $4 \mathrm{yr}$ of age or older. That result is consistent with the present study for dams calving at $3 \mathrm{yr}$ of age. However, the present study indicates Longhorns have a significant advantage in calving ease over Red Poll sires for dams calving at $2 \mathrm{yr}$ of age. Results from the present and previous studies have indicated that progeny of Longhorn sires were significantly lighter at birth and weaning than were progeny of Red Poll sires that were comparable with Hereford-Angus crosses by reference sires born in the 1960s (reference sires were Hereford and Angus bulls born in the late 1960s used in Cycles I, II, III, and IV) but lighter than Hereford-Angus cross progeny sired by a more recent sam- ple of Hereford and Angus bulls born in the mid1980s (Cundiff et al., 1993). Previously, post-weaning average daily gains and slaughter weights adjusted for age were less $(P<0.05)$ for progeny of Longhorn sires than for progeny of Red Poll sires when derived from analyses pooled over Cycles II and IV of the GPE Program (Cundiff et al., 1993). In addition, carcasses from progeny of Longhorn sires had significantly greater percentages of retail product than progeny of Red Poll sires, which were comparable with Hereford-Angus cross progeny by reference sires born in the 1960s or more recently sampled sires born in the mid 1980s (Cundiff et al., 1993). Although fat trim percentages of Red Poll-sired progeny were comparable with those of Hereford-Angus crosses in Cycle II, progeny by Red Poll sires had significantly greater percentages of kidney, pelvic, and heart fat but significantly less subcutaneous fat thickness than Hereford-Angus cross progeny by reference sires born in the 1960s or more recently sampled sires born in the mid 1980s. Results from the previous studies indicate that progeny by Longhorn sires 
had even less subcutaneous fat thickness and greater percentages of kidney, pelvic, and heart fat than progeny by Red Poll sires. Estimates of total fat trim percentage were less in Longhorn-sired progeny than in Red Poll-sired progeny, although the difference was not significant in this study. Marbling scores and percentages of carcasses grading USDA Choice were comparable for Red Polland Longhorn-sired progeny and significantly less than that for HerefordAngus cross progeny by reference sires.

\section{Implications}

Results of the present and previous studies indicate that Longhorns should be characterized as a different biological type than Hereford, Angus, and Red Poll with respect to birth weight, calving ease, and growth rate. Longhorns have lighter birth weight and greater calving ease than British breeds such as the Red Poll, Angus, and Hereford. Longhorns are lighter in weight at weaning and yearling ages, but produce carcasses with slightly greater lean-to-fat ratios than British breeds. In progeny of 2-yr-old dams, the significant advantage of less calving difficulty for progeny of Longhorn sires must be balanced against heavier weaning weights and slightly heavier slaughter weights expected for progeny of Red Poll sires.

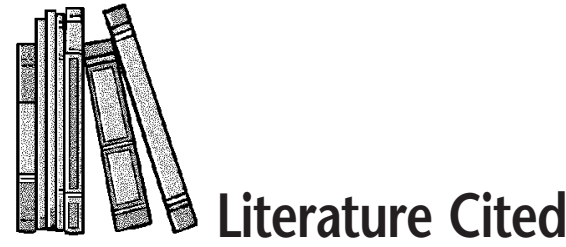

Beef Improvement Federation. 1996. Guidelines For Uniform Beef Improvement Programs. [Online.] Available: www.beefimprovement.org/guidelines.html.

Boldman, K. G., L. A. Kriese, L. D. Van Vleck, C. P. Van Tassell, and S. D. Kachman. 1995. A Manual for use of MTDFREML. A set of programs to obtain estimates of variances and covariances [draft]. USDA, ARS, Dep. Anim. Sci., Univ. Nebraska, Lincoln.

Cundiff, L. V., K. E. Gregory, and R. M. Koch. 1998. Germplasm evaluation in beef cattleCycle IV: Birth and weaning traits. J. Anim. Sci. 76:2528.

Cundiff, L. V., F. Szabo, K. E. Gregory, R. M. Koch, M. E. Dikeman, and J. D. Crouse. 1993. Breed comparisons in the Germplasm Evaluation Program at MARC. The Beef Improvement Federation 25th Anniversary Conf., Asheville, NC.

Gregory, K. E., L. V. Cundiff, and R. M. Koch. 1991. Breed effects and heterosis in advanced generations of composite populations for pre- weaning traits of beef cattle. J. Anim. Sci. 69:947.

Gregory, K. E., L. V. Cundiff, G. M. Smith, D. B. Laster, and H. A. Fitzhugh, Jr. 1978. Characterization of biological types of cattle-Cycle II: I. Birth and weaning traits. J. Anim. Sci. 47:1022.

Koch, R. M., M. E. Dikeman, R. J. Lipsey, D. M. Allen, and J. D. Crouse. 1979. Characterization of biological types of cattle-Cycle II: III. Carcass composition, quality, and palatability. J. Anim. Sci. 49:448.

Koch, R. M., L. V. Cundiff, and K. E. Gregory. 1982. Influence of postweaning gain interval on estimates of heritability and genetic correlations. J. Anim. Sci. 55:1310.

Olson, T. A., K. Euclides Filho, L. V. Cundiff, M. Koger, W. T. Butts, Jr., and K. E. Gregory. 1991. Effects of breed group by location interaction on crossbred cattle in Nebraska and Florida. J. Anim. Sci. 69:104.

Shackelford, S. D., L. V. Cundiff, K. E. Gregory, and M. Koohmaraie.1995. Predicting beef carcass cutability. J. Anim. Sci. 73:406.

Thrift, F. A., D. E. Franke, and D. K. Aaron. 1986. Preweaning breed-of-sire comparisons involving the Senepole breed of cattle. J. Anim. Sci. 62:1247.

Wheeler, T. L., L. V. Cundiff, R. M. Koch, M. E. Dikeman, and J. D. Crouse. 1997. Characterization of different biological types of steers (Cycle IV): Wholesale, subprimal, and retail product yields. J. Anim. Sci. 75:2389.

Wheeler, T. L., L. V. Cundiff, S. D. Shackelford, and M. Koohmaraie. 2001. Characterization of biological types of cattle (Cycle V). Carcass traits and longissimus palatability. J. Anim. Sci. 79:1209. 